\title{
The inhibitory effect of Gleditsia sinensis on cyclooxygenase-2 expression in human esophageal squamous cell carcinoma
}

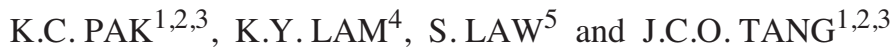 \\ ${ }^{1}$ Lo Ka Chung Centre for Natural Anti-cancer Drug Development, ${ }^{2}$ State Key Laboratory of Chinese Medicine and Molecular \\ Pharmacology, ${ }^{3}$ Department of Applied Biology and Chemical Technology, The Hong Kong Polytechnic University, \\ Hong Kong SAR, P.R. China; ${ }^{4}$ Griffith Medical School, Griffith University, Australia; ${ }^{5}$ Department of Surgery, \\ The University of Hong Kong, Hong Kong SAR, P.R. China
}

Received August 25, 2008; Accepted October 1, 2008

DOI: 10.3892/ijmm_00000109

\begin{abstract}
The anti-cancer effects of the anomalous fruit extract of Gleditsia sinensis (GSE) attributed to its apoptotic activity, telomerase inhibition and anti-angiogenesis in a panel of solid and non-solid tumor cell lines including esophageal squamous cell carcinoma (ESCC) have been intensively investigated by us in previous studies. Cyclooxygenase- 2 (COX-2) has been well described as another promising target of cancer therapy for ESCC, and novel therapeutic agents are still being sought which target COX-2 expression. However, the anti-cancer effect of GSE through the suppression of COX-2 expression has not been previously investigated. In the present study, the anti-cancer effects of GSE on eight ESCC cell lines (KYSE 30, KYSE 150, KYSE 450, KYSE 510, KYSE 520, HKESC-3, HKESC-4 and SLMT-1) of Chinese and Japanese origins were first studied by MTS cytotoxicity assays. The effects of GSE on COX-2 expression levels and on the housekeeping form COX-1 were also investigated by multiplex RT-PCR analysis. Moreover, the anti-proliferative effect of GSE on KYSE 510 was also studied by anchorageindependent clonogenicity assay in soft agar. The results showed that GSE induced a dose- and time-dependent cytotoxicity on all of the eight ESCC cell lines and caused positive anti-proliferative action on KYSE 510 in the anchorage-independent clonogenicity assay, suggesting that GSE suppressed the in vitro growth of the ESCC cell lines. More importantly, the MRNA expression levels of COX-2, but not COX-1, in all of the ESCC cell lines were suppressed by GSE in a dose-dependent fashion. The overall results of the present study show that the anti-cancer effect of GSE on the
\end{abstract}

Correspondence to: Dr Johnny Cheuk On Tang, Department of Applied Biology and Chemical Technology, The Hong Kong Polytechnic University, Hung Hom, Hong Kong, SAR, P.R. China E-mail: bccotang@inet.polyu.edu.hk

Key words: esophageal squamous cell carcinoma, gene overexpression, cyclooxygenase-2, anti-proliferation
ESCC cell lines is associated with the suppression of COX-2 expression, but not COX-1. Our findings also open a new chapter for the future advancement of GSE as a novel anticancer agent or as an adjuvant of traditional cancer treatments.

\section{Introduction}

Esophageal cancer is characterized by a relatively poor prognosis and is the sixth most common cause of cancerrelated death in the world (1). The relatively high incidence of esophageal squamous cell carcinoma (ESCC) among the Chinese may suggest the involvement of a unique mode of pathogenicity in this population (2). Although many efforts have been devoted to the advancement of a variety of diagnostic techniques and treatments including resection, chemotherapies, radiotherapies and multimodality therapies, this disease is still associated with a low 5-year survival rate (3).

Cyclooxygenase (COX), also known as prostaglandin enderoperoxide $\mathrm{H}$ synthase or prostaglandin $\mathrm{H}_{2}$ synthase (PGHS), is a homodimer, heme-dependent, bi-functional, membrane-bound enzyme (EC. 1.14.99.1). It is responsible for catalyzing the rate-limiting step in the biosynthesis of prostanoids which is a class of biological mediators such as prostaglandins (PGs), leukotrienes (LTs), thromboxanes and prostacyclin by converting arachidonic acid, a 20-carbon fatty acid substrate to prostaglandin $\mathrm{H}_{2}\left(\mathrm{PGH}_{2}\right)$ (4). There are two isoforms which are cyclooxygenase-1 (COX-1) and -2 (COX-2). COX-1 is a housekeeping gene which is expressed constitutively under most circumstances in most normal tissues. The functions of COX-1 include the maintenance of normal physiological activities and homeostatic regulations such as blood clotting by platelets, gastrointestinal cytoprotection, and renal blood flow (5). In contrast, COX-2 is an inducible enzyme and rarely expressed in most tissues except in the brain and kidney (5). The expression of COX-2, however, is dramatically increased upon stimulation by a wide range of inducers including proinflammatory factors such as lipopolysaccharide (LPS), cytokines, mitogens, interleukin, tumor necrosis factor (TNF), hormones such as folliclestimulating hormones (FSH), growth factors and oncoproteins including $\mathrm{v}$-src and v-ras (6). COX-2 and its derived 
prostanoids such as prostaglandin $\mathrm{E}_{2}\left(\mathrm{PGE}_{2}\right)$ essentially participate in different pathophysiological processes, for example, inflammation, fever, carcinogenesis and adaptation including wound healing, implantation and bone metabolism (7).

Overexpression of COX-2 has been commonly found in a variety of cancers including esophageal cancer (8). It has also been demonstrated that COX-2 overexpression is sufficient to induce tumorigenesis in transgenic mice (9). In addition, compelling clinical evidence shows that COX-2 plays different roles in carcinogenesis by recruiting a number of mechanisms including enhanced cellular proliferation (10), anti-apoptotsis (11), angiogenesis (12), metastasis (13), inflammation (14), immune surveillance (15) and multidrug resistance (16). These findings provide evidence that the substantial inhibition of COX-2 can be the focus of novel therapy or prevention for a panel of cancers including breast, colorectal and ESCC (17-19). However, some of these agents result in side effects of different degrees such as the increased risk of renal failure (20) and myocardial infarction (21). Thus, novel agents for inhibiting COX-2 in cancers remain to be identified.

Gleditsia sinensis (GS) is a traditional Chinese herb widely distributed in the Chinese mainland (22). The anomalous fruit of GS collected from old or injured GS plants is rich in saponins such as triterpenoidal saponins (23) and bears proven therapeutic effects $(24,25)$. The anti-cancer effects of Gleditsia sinensis fruit extract (GSE) on a panel of solid tumor cell lines and leukemia (26) have been widely studied by our group. Different modes of anti-cancer mechanisms employed by GSE include the generation of fibroblast growth factor (bFGF) and nitric oxide (27), angiogenesis suppression via inhibiting the vascular endothelial growth factor (VEGF) mRNA expression (28), hydrogen peroxide generation, disruption of the acid-base equilibrium, depolarization of mitochondrial membrane potential, activation of capase 3 protease activity (29), inhibition of proteasome activity (30), generation of superoxide anion with the resulting apoptosis (31), and suppression of telomerase and oncogene expression (32). However, the effect of GSE on COX-2 expression in ESCC has not been previously investigated, and further study of GSE for its action on COX-2 expression will be beneficial for developing GS as an alternative anti-cancer agent. The purpose of the present study was to further investigate the anti-cancer effect of GSE and its suppression on COX-2 expression in a panel of ESCC cell lines. The current findings will provide us with a more comprehensive picture of the anticancer effects of GSE for the possible future development of targeted therapy for ESCC or other types of cancers.

\section{Materials and methods}

Preparation of Gleditsia sinensis fruit extract (GSE). The dried fruit of Gleditsia sinensis was ground into powder using a mortar and a pestle. The preparation of ethanol extract and the measurement of the concentration of the working samples were followed as described previously by our group (27).

Esophageal squamous cell carcinoma cell lines. Three ESCC cell lines of Hong Kong Chinese origin, including HKESC-3 (33), HKESC-4 (34) and SLMT-1 (35), were cultured as previously described $(34,35)$. The KYSE series of cell lines including KYSE 30, 150, 450, 510 and 520 were purchased from DSMZ (Braunschweig, Germany) (36). All the cell lines were cultured as previously described $(32,37)$. NE1, an immortalized non-tumor esophageal epithelial cell line (38), was kindly provided by Professor George S.W. Tsao, Department of Anatomy, The University of Hong Kong, and maintained as described (37).

MTS cytotoxicity assay. The growth inhibitory effects of GSE and cisplatin (CDDP, Sigma-Aldrich) on the eight ESCC and NE1 cell lines at incubation times of 24,48 and $72 \mathrm{~h}$ were studied using MTS [3-(4,5-dimethylthiazol-2-yl)-5-(3carboxymethoxyphenyl)-2-(4-sulfophenyl)-2H-tetrazolium] assay as previously described with the use of CellTiter96 ${ }^{\circledR}$ Aqueous One Solution cell proliferation cell assay (Promega) (32).

Anchorage-independent clonogenicity assay. The clonogenicity assay for KYSE 510 was conducted as previously described with the base agarose layer composed of different GSE concentrations: $0,3.125,6.25,12.5,25,50,100$ and $200 \mu \mathrm{g} / \mathrm{ml}$ (22).

RT-PCR analysis. The extraction of total RNA of both ESCC and non-tumor esophageal epithelial cell lines was conducted using the RNeasy Mini Kit (Qiagen) according to the manufacturer's protocol. The mRNA expression levels of $C O X-1$ and $C O X-2$ in NE1 and the ESCC cell lines with or without GSE or CDDP treatments were studied. cDNA $(2 \mu \mathrm{g})$ synthesized from the RNA through reverse transcription was amplified by using the specific PCR primers of $C O X-1$ and $C O X-2$. The expression of $\beta$-actin was used as an internal control for the normalization of the cDNA amount. The multiplex PCR was performed as previously described (37), except the annealing temperatures of both $C O X-1$ and -2 genes were $52^{\circ} \mathrm{C}$. The primer sequences for the $C O X-1$ expression study (39) were: $C O X-1-\mathrm{F}, 5^{\prime}-\mathrm{GTT}$ CAA CAC CTC CAT GTT GGT GGA C-3' and $C O X-1$-R, 5'-TGG TGT TGA GGC AGA CCA GCT TC-3'. The primers for $C O X-2$ were $C O X-2-\mathrm{L} 2,5^{\prime}$-TGC TGA ATT TAA CAC CCT CT-3' and $C O X-2-\mathrm{R} 2,5^{\prime}-\mathrm{CCA}$ TAG AGT GCT TCC AAC TC-3' (Integrated DNA Technologies, Inc.). The primers for $\beta$-actin (40) were: Actin-F, 5'-CTC CTT AAT GTC ACG CAC GAT TTC-3' and Actin-R, 5'-GTG GGG CGC CCC AGG CAC CA-3'. The PCR products of $C O X-1$ and $C O X-2$ were then resolved in a 1.5 and $1 \%$ agarose gel, respectively, and visualized under UV illumination. The intensities of PCR products were quantified by Quantity One program (Bio-Rad). The intensity of each target PCR product was normalized against that of $\beta$-actin expression in each sample. Expression of each target gene, in terms of ratio, was expressed relative to the untreated control or NE1 by the formula: [ $C O X-1$ or $C O X-2) / \beta$-actin, for the ESCC cell line with or without drug intervention $) /(C O X-1$ or $C O X-2) / \beta$-actin, for $\mathrm{NE} 1$ or the untreated control)] as previously described (41). Three classes of relative expression levels were: a ratio $<0.8$ treated as underexpression; a ratio between 0.8 and 1.2 regarded as no change; and a ratio $>1.2$ interpreted as gene overexpression as described previously (42). 
A

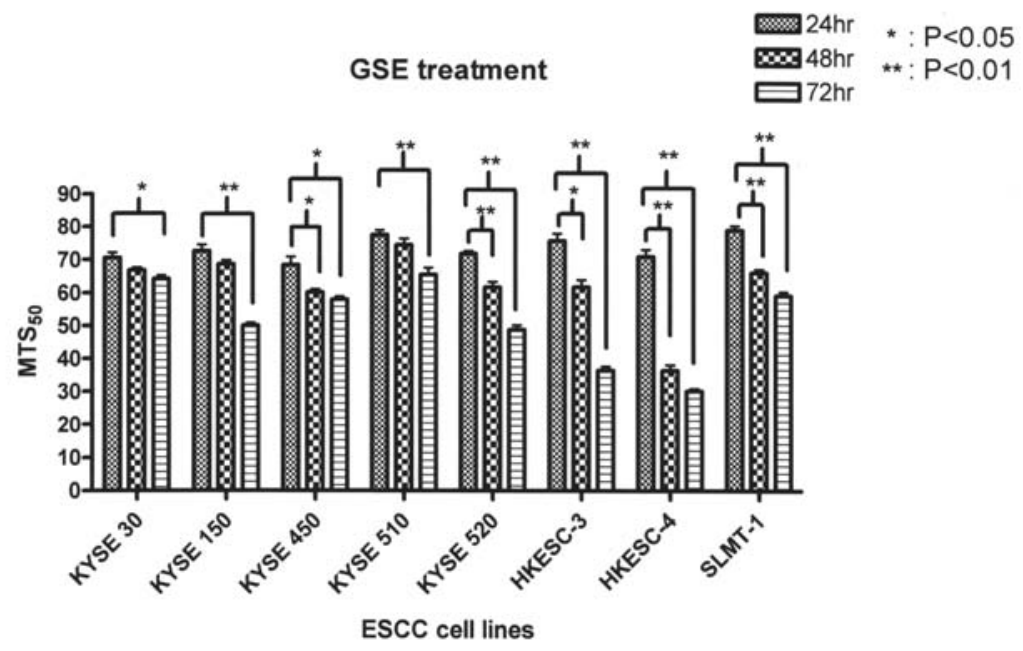

B
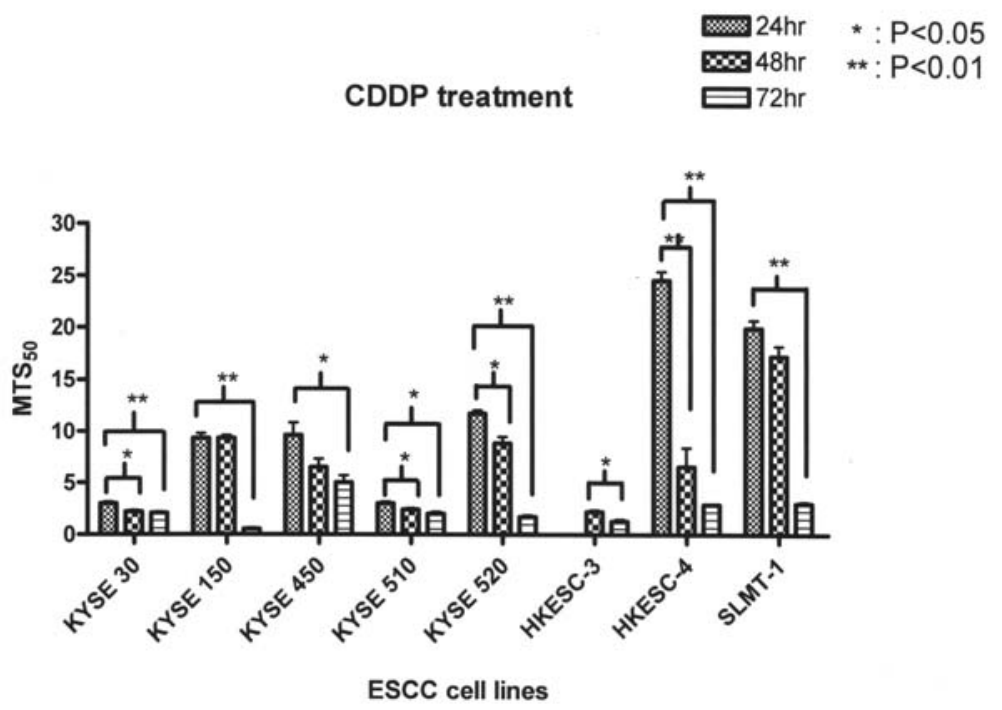

Figure 1. The time-dependent effects of different drug treatments on the 8 ESCC cell lines. The cytotoxicity of GSE (A) and CDDP (B) on ESCC after 24,48 and $72 \mathrm{~h}$ of incubation. The results are summarized in Table I.

\section{Results}

MTS cytotoxicity assay. The results of MTS assays performed on all of the 8 ESCC cell lines showed a dose-dependent decrease in cell viabilities. Table I summarises the $\mathrm{MTS}_{50}$ (i.e. the decrease in MTS activity by half compared with the negative controls) values for different periods of incubation. Fig. 1 shows the time-dependent change in $\mathrm{MTS}_{50}$ values of all the studied cell lines treated with GSE and CDDP, respectively. The MTS assays showed that $\mathrm{MTS}_{50}$ values of GSE for the ESCC cell lines of Hong Kong Chinese origin (HKESC-3, HKESC-4 and SLMT-1) ranged from 30.2 to $59.2 \mu \mathrm{g} / \mathrm{ml}$ and those of KYSE 30, 150, 450, 510 and 520 ranged from 48.8 to $65.4 \mu \mathrm{g} / \mathrm{ml}$ after $72 \mathrm{~h}$ of treatment with GSE. The viabilities of all the cell lines were reduced with an increase in the duration of the GSE treatment $(\mathrm{p}<0.05)$ (Fig. 1A). For the positive controls with CDDP treatment, MTS $_{50}$ for HKESC-3, HKESC-4 and SLMT-1 ranged from 1.3 to $3.0 \mu \mathrm{g} / \mathrm{ml}$ while $\mathrm{MTS}_{50}$ values for the studied KYSE series cell lines were between 0.5 and $5.0 \mu \mathrm{g} / \mathrm{ml}$ after $72 \mathrm{~h}$ of treatment (Fig. 1B). The overall MTS results showed that GSE exhibited a cytotoxic effects on all of the ESCC cell lines in both a doseand time-dependent manner.

Anchorage-independent clonogenicity assay. KYSE 510 was chosen for the clonogenicity assay due to its fast growth rate and positive colony formation characteristics (36). The result showed that the inhibitory effect of GSE on the colonyformation of KYSE 510 was dose-dependent. GSE $(5 \mu \mathrm{g} / \mathrm{ml})$ induced a $50 \%$ reduction in the colony formation of KYSE 510 , and the colony-forming ability was negligible once the GSE dose reached $100 \mu \mathrm{g} / \mathrm{ml}$ (Fig. 2).

RT-PCR analysis. Without GSE treatment, 11 out of the 13 $(84.6 \%)$ studied ESCC cell lines showed overexpression of COX-2 compared with the non-tumor NE1 cell line. Representative examples are shown in Fig. 3, and the summary of COX-2 expression levels are shown in Table II. 
Table I. Summary of MTS $_{50}$ values of 8 ESCC cell lines and the non-tumor NE1 cell line after GSE or CDDP treatment for 24, 48 and 72 h. $^{\mathrm{a}}$

\begin{tabular}{|c|c|c|c|c|c|c|}
\hline \multirow[b]{3}{*}{ Cell line } & \multicolumn{6}{|c|}{$\operatorname{MTS}_{50}(\mu \mathrm{g} / \mathrm{ml})$} \\
\hline & \multicolumn{3}{|c|}{ GSE } & \multicolumn{3}{|c|}{ CDDP } \\
\hline & $24 \mathrm{~h}$ & $48 \mathrm{~h}$ & $72 \mathrm{~h}$ & $24 \mathrm{~h}$ & $48 \mathrm{~h}$ & $72 \mathrm{~h}$ \\
\hline KYSE 30 & $70.6 \pm 2.8$ & $66.8 \pm 1.4$ & $64.2 \pm 1.6$ & $3.0 \pm 0.3$ & $2.2 \pm 0.2$ & $2.1 \pm 0.1$ \\
\hline KYSE 150 & $72.5 \pm 3.4$ & $68.6 \pm 2.1$ & $50.0 \pm 1.4$ & $9.3 \pm 0.8$ & $9.3 \pm 0.7$ & $0.5 \pm 0.2$ \\
\hline KYSE 450 & $68.3 \pm 4.5$ & $60.1 \pm 1.6$ & $57.9 \pm 1.6$ & $9.6 \pm 2.1$ & $6.5 \pm 1.4$ & $5.0 \pm 1.2$ \\
\hline KYSE 510 & $77.4 \pm 2.5$ & $74.4 \pm 3.3$ & $65.4 \pm 3.7$ & $3.0 \pm 0.3$ & $2.4 \pm 0.2$ & $2.0 \pm 0.3$ \\
\hline KYSE 520 & $71.8 \pm 1.3$ & $61.7 \pm 2.8$ & $48.8 \pm 2.4$ & $11.7 \pm 0.5$ & $8.8 \pm 1.1$ & $1.7 \pm 0.3$ \\
\hline HKESC-3 & $75.7 \pm 3.8$ & $61.8 \pm 3.6$ & $36.6 \pm 1.9$ & N/A & $2.2 \pm 0.3$ & $1.3 \pm 0.3$ \\
\hline HKESC-4 & $71.0 \pm 3.6$ & $36.6 \pm 2.7$ & $30.2 \pm 1.1$ & $24.5 \pm 1.5$ & $6.6 \pm 3.1$ & $2.9 \pm 0.1$ \\
\hline SLMT-1 & $79.0 \pm 2.3$ & $66.0 \pm 1.7$ & $59.2 \pm 2.1$ & $19.9 \pm 1.3$ & $17.2 \pm 1.7$ & $3.0 \pm 0.3$ \\
\hline NE1 & $23.5 \pm 2.1$ & $20.3 \pm 2.5$ & $18.0 \pm 2.0$ & N/A & $1.0 \pm 0.1$ & $0.5 \pm 0.1$ \\
\hline
\end{tabular}

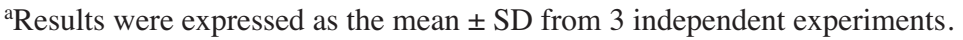

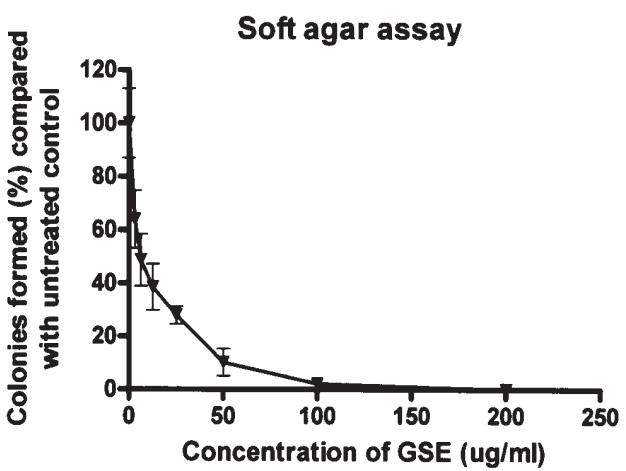

Figure 2. Suppression on KYSE 510 colony formation after $48 \mathrm{~h}$ GSE intervention with concentrations of $0,3.125,6.25,12.5,25,50,100$ and $200 \mu \mathrm{g} / \mathrm{ml}$. Results are representative of three independent experiments.

A

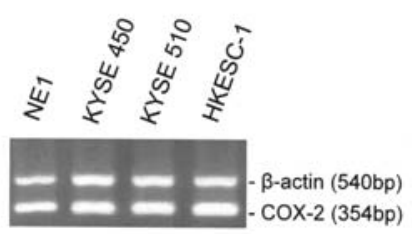

B

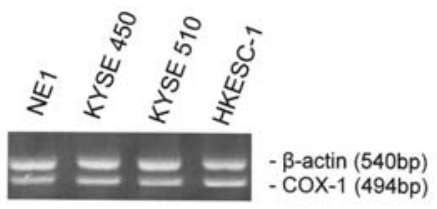

Figure 3. Representative examples of the results of the multiplex RT-PCR analysis on COX-2 and -1 expression in untreated ESCC cell lines. The expression levels of target genes were relative to the non-tumor esophageal epithelial cell line NE1. (A) Expression studies of COX-2 and (B) COX-1. All the examples show overexpression of COX-2 except KYSE 450, but not COX-1. The relative expression levels of the studied ESCC cell lines are shown in Table II.
Table II. Expression levels of COX-2 and COX-1 mRNA in the ESCC cell lines.

\begin{tabular}{|c|c|c|c|c|}
\hline $\begin{array}{l}\text { ESCC } \\
\text { cell } \\
\text { lines }\end{array}$ & $\begin{array}{c}\text { Relative } \\
\text { COX-2 } \\
\text { expression }^{\mathrm{a}}\end{array}$ & $\begin{array}{l}\text { Expression } \\
\text { status } \\
\text { of COX-2 }\end{array}$ & $\begin{array}{c}\text { Relative } \\
\text { COX-1 } \\
\text { expression }\end{array}$ & $\begin{array}{l}\text { Expression } \\
\text { status } \\
\text { of } \mathrm{COX}-1\end{array}$ \\
\hline KYSE 30 & 1.6 & $\mathrm{O}$ & 1.0 & $\mathrm{NC}$ \\
\hline KYSE 70 & 0.7 & $\mathrm{U}$ & 0.6 & $\mathrm{U}$ \\
\hline KYSE 140 & 1.7 & $\mathrm{O}$ & 1.1 & $\mathrm{NC}$ \\
\hline KYSE 150 & 2.4 & $\mathrm{O}$ & 0.9 & $\mathrm{NC}$ \\
\hline KYSE 180 & 3.5 & $\mathrm{O}$ & 0.6 & $\mathrm{U}$ \\
\hline KYSE 410 & 9.5 & $\mathrm{O}$ & 1.0 & $\mathrm{NC}$ \\
\hline KYSE 450 & 1.1 & $\mathrm{NC}$ & 1.0 & $\mathrm{NC}$ \\
\hline KYSE 510 & 11.2 & $\mathrm{O}$ & 1.1 & $\mathrm{NC}$ \\
\hline KYSE 520 & 10.9 & $\mathrm{O}$ & 1.0 & $\mathrm{NC}$ \\
\hline HKESC-1 & 9.9 & $\mathrm{O}$ & 0.8 & $\mathrm{NC}$ \\
\hline HKESC-3 & 7.9 & $\mathrm{O}$ & 0.9 & $\mathrm{NC}$ \\
\hline HKESC-4 & 8.2 & $\mathrm{O}$ & 1.1 & $\mathrm{NC}$ \\
\hline SLMT-1 & 12.2 & $\mathrm{O}$ & 1.1 & $\mathrm{NC}$ \\
\hline
\end{tabular}

$\mathrm{U}$, underexpression; $\mathrm{NC}$, no change in expression; $\mathrm{O}$, overexpression. ${ }^{a}$ The relative expression of target genes COX-1 and -2 was calculated by the equation: (target gene/ß-actin, ESCC cell line)/(target gene/ß-actin, non-tumor NE1) and corresponding to 1 decimal place. The relative expression level was interpreted as underexpression when the calculated ratio was $<0.8$; regarded as no change when the ratio was between 0.8 and 1.2; and was treated as overexpression when the ratio was $>1.2$. See Materials and methods for details.

However, the COX-2 levels of KYSE 70 and KYSE 450 were underexpressed and no change, respectively (Table II). Without GSE treatment, the expression of COX-1, a housekeeping gene, was also investigated. All of the studied ESCC cell lines except KYSE 70 and KYSE 180 (11/13) showed no 
Table III. COX-2 and COX-1 expression levels in the ESCC cell lines after different treatments with GSE and CDDP.

\begin{tabular}{|c|c|c|c|c|c|c|}
\hline \multirow[b]{2}{*}{ ESCC cell line } & \multirow{2}{*}{\multicolumn{2}{|c|}{ Treatment }} & \multicolumn{2}{|c|}{ COX-2 } & \multicolumn{2}{|c|}{ COX-1 } \\
\hline & & & Relative expression ${ }^{a}$ & Expression status & Relative expression ${ }^{a}$ & Expression status \\
\hline \multirow[t]{8}{*}{ KYSE 30} & \multicolumn{2}{|c|}{$0.05 \%$ ethanol } & 1.1 & $\mathrm{NC}$ & 1.0 & $\mathrm{NC}$ \\
\hline & GSE & $50 \mu \mathrm{g} / \mathrm{ml}$ & 1.0 & $\mathrm{NC}$ & 1.1 & $\mathrm{NC}$ \\
\hline & & $75 \mu \mathrm{g} / \mathrm{ml}$ & 0.3 & $\mathrm{U}$ & 1.0 & $\mathrm{NC}$ \\
\hline & & $100 \mu \mathrm{g} / \mathrm{ml}$ & 0.1 & $\mathrm{U}$ & 0.9 & $\mathrm{NC}$ \\
\hline & & $200 \mu \mathrm{g} / \mathrm{ml}$ & 0.0 & $\mathrm{U}$ & 0.8 & $\mathrm{NC}$ \\
\hline & CDDP & $1 \mu \mathrm{g} / \mathrm{ml}$ & 1.1 & $\mathrm{NC}$ & 1.1 & $\mathrm{NC}$ \\
\hline & & $5 \mu \mathrm{g} / \mathrm{ml}$ & 0.7 & $\mathrm{U}$ & 0.9 & $\mathrm{NC}$ \\
\hline & & $10 \mu \mathrm{g} / \mathrm{ml}$ & 0.0 & $\mathrm{U}$ & 0.9 & $\mathrm{NC}$ \\
\hline \multirow[t]{8}{*}{ KYSE 150} & \multicolumn{2}{|c|}{$0.05 \%$ ethanol } & 1.0 & $\mathrm{NC}$ & 0.9 & $\mathrm{NC}$ \\
\hline & GSE & $50 \mu \mathrm{g} / \mathrm{ml}$ & 1.1 & $\mathrm{NC}$ & 0.9 & $\mathrm{NC}$ \\
\hline & & $75 \mu \mathrm{g} / \mathrm{ml}$ & 0.9 & $\mathrm{NC}$ & 0.8 & $\mathrm{NC}$ \\
\hline & & $100 \mu \mathrm{g} / \mathrm{ml}$ & 0.0 & $\mathrm{U}$ & 1.1 & $\mathrm{NC}$ \\
\hline & & $200 \mu \mathrm{g} / \mathrm{ml}$ & 0.0 & $\mathrm{U}$ & 1.0 & $\mathrm{NC}$ \\
\hline & CDDP & $1 \mu \mathrm{g} / \mathrm{ml}$ & 0.9 & $\mathrm{NC}$ & 1.0 & $\mathrm{NC}$ \\
\hline & & $5 \mu \mathrm{g} / \mathrm{ml}$ & 0.8 & $\mathrm{NC}$ & 0.8 & $\mathrm{NC}$ \\
\hline & & $10 \mu \mathrm{g} / \mathrm{ml}$ & 0.7 & $\mathrm{U}$ & 1.1 & $\mathrm{NC}$ \\
\hline \multirow[t]{8}{*}{ KYSE 450} & \multicolumn{2}{|c|}{$0.05 \%$ ethanol } & 1.0 & $\mathrm{NC}$ & 0.9 & $\mathrm{NC}$ \\
\hline & GSE & $50 \mu \mathrm{g} / \mathrm{ml}$ & 0.9 & $\mathrm{NC}$ & 0.9 & $\mathrm{NC}$ \\
\hline & & $75 \mu \mathrm{g} / \mathrm{ml}$ & 0.7 & $\mathrm{U}$ & 1.1 & $\mathrm{NC}$ \\
\hline & & $100 \mu \mathrm{g} / \mathrm{ml}$ & 0.0 & $\mathrm{U}$ & 0.9 & $\mathrm{NC}$ \\
\hline & & $200 \mu \mathrm{g} / \mathrm{ml}$ & 0.0 & $\mathrm{U}$ & 1.1 & $\mathrm{NC}$ \\
\hline & CDDP & $1 \mu \mathrm{g} / \mathrm{ml}$ & 1.1 & $\mathrm{NC}$ & 0.9 & $\mathrm{NC}$ \\
\hline & & $5 \mu \mathrm{g} / \mathrm{ml}$ & 1.0 & $\mathrm{NC}$ & 0.8 & $\mathrm{NC}$ \\
\hline & & $10 \mu \mathrm{g} / \mathrm{ml}$ & 0.8 & $\mathrm{NC}$ & 1.0 & $\mathrm{NC}$ \\
\hline \multirow[t]{8}{*}{ KYSE 510} & \multicolumn{2}{|c|}{$0.05 \%$ ethanol } & 1.1 & $\mathrm{NC}$ & 1.0 & $\mathrm{NC}$ \\
\hline & GSE & $50 \mu \mathrm{g} / \mathrm{ml}$ & 0.9 & $\mathrm{NC}$ & 0.9 & $\mathrm{NC}$ \\
\hline & & $75 \mu \mathrm{g} / \mathrm{ml}$ & 1.0 & $\mathrm{NC}$ & 0.9 & $\mathrm{NC}$ \\
\hline & & $100 \mu \mathrm{g} / \mathrm{ml}$ & 0.9 & $\mathrm{NC}$ & 1.1 & $\mathrm{NC}$ \\
\hline & & $200 \mu \mathrm{g} / \mathrm{ml}$ & 0.0 & $\mathrm{U}$ & 1.0 & $\mathrm{NC}$ \\
\hline & CDDP & $1 \mu \mathrm{g} / \mathrm{ml}$ & 0.9 & $\mathrm{NC}$ & 1.1 & $\mathrm{NC}$ \\
\hline & & $5 \mu \mathrm{g} / \mathrm{ml}$ & 0.5 & $\mathrm{U}$ & 0.9 & $\mathrm{NC}$ \\
\hline & & $10 \mu \mathrm{g} / \mathrm{ml}$ & 0.4 & $\mathrm{U}$ & 1.0 & $\mathrm{NC}$ \\
\hline \multirow[t]{8}{*}{ KYSE 520} & \multicolumn{2}{|c|}{$0.05 \%$ ethanol } & 0.9 & $\mathrm{NC}$ & 0.8 & $\mathrm{NC}$ \\
\hline & GSE & $50 \mu \mathrm{g} / \mathrm{ml}$ & 1.0 & $\mathrm{NC}$ & 0.8 & $\mathrm{NC}$ \\
\hline & & $75 \mu \mathrm{g} / \mathrm{ml}$ & 0.7 & $\mathrm{U}$ & 1.0 & $\mathrm{NC}$ \\
\hline & & $100 \mu \mathrm{g} / \mathrm{ml}$ & 0.3 & $\mathrm{U}$ & 0.9 & $\mathrm{NC}$ \\
\hline & & $200 \mu \mathrm{g} / \mathrm{ml}$ & 0.0 & $\mathrm{U}$ & 1.1 & $\mathrm{NC}$ \\
\hline & CDDP & $1 \mu \mathrm{g} / \mathrm{ml}$ & 1.0 & $\mathrm{NC}$ & 1.1 & $\mathrm{NC}$ \\
\hline & & $5 \mu \mathrm{g} / \mathrm{ml}$ & 1.0 & $\mathrm{NC}$ & 1.0 & $\mathrm{NC}$ \\
\hline & & $10 \mu \mathrm{g} / \mathrm{ml}$ & 1.0 & $\mathrm{NC}$ & 0.8 & $\mathrm{NC}$ \\
\hline \multirow[t]{8}{*}{ HKESC-3 } & \multicolumn{2}{|c|}{$0.05 \%$ ethanol } & 0.9 & $\mathrm{NC}$ & 1.0 & $\mathrm{NC}$ \\
\hline & GSE & $50 \mu \mathrm{g} / \mathrm{ml}$ & 0.4 & $\mathrm{U}$ & 1.1 & $\mathrm{NC}$ \\
\hline & & $75 \mu \mathrm{g} / \mathrm{ml}$ & 0.4 & $\mathrm{U}$ & 1.0 & $\mathrm{NC}$ \\
\hline & & $100 \mu \mathrm{g} / \mathrm{ml}$ & 0.3 & $\mathrm{U}$ & 1.1 & $\mathrm{NC}$ \\
\hline & & $200 \mu \mathrm{g} / \mathrm{ml}$ & 0.0 & $\mathrm{U}$ & 1.0 & $\mathrm{NC}$ \\
\hline & CDDP & $1 \mu \mathrm{g} / \mathrm{ml}$ & 0.9 & $\mathrm{NC}$ & 1.1 & $\mathrm{NC}$ \\
\hline & & $5 \mu \mathrm{g} / \mathrm{ml}$ & 1.0 & $\mathrm{NC}$ & 0.9 & $\mathrm{NC}$ \\
\hline & & $10 \mu \mathrm{g} / \mathrm{ml}$ & 1.0 & $\mathrm{NC}$ & 1.0 & $\mathrm{NC}$ \\
\hline
\end{tabular}


Table III. Continued.

\begin{tabular}{|c|c|c|c|c|c|c|}
\hline \multirow[b]{2}{*}{ ESCC cell line } & \multirow{2}{*}{\multicolumn{2}{|c|}{ Treatment }} & \multicolumn{2}{|c|}{ COX-2 } & \multicolumn{2}{|c|}{ COX-1 } \\
\hline & & & Relative expression $^{a}$ & Expression status & Relative expression $^{a}$ & Expression status \\
\hline \multirow[t]{8}{*}{ HKESC-4 } & \multicolumn{2}{|c|}{$0.05 \%$ ethanol } & 1.1 & $\mathrm{NC}$ & 1.0 & $\mathrm{NC}$ \\
\hline & \multirow[t]{4}{*}{ GSE } & $50 \mu \mathrm{g} / \mathrm{ml}$ & 0.3 & $\mathrm{U}$ & 1.0 & $\mathrm{NC}$ \\
\hline & & $75 \mu \mathrm{g} / \mathrm{ml}$ & 0.3 & $\mathrm{U}$ & 0.9 & $\mathrm{NC}$ \\
\hline & & $100 \mu \mathrm{g} / \mathrm{ml}$ & 0.0 & $\mathrm{U}$ & 0.9 & $\mathrm{NC}$ \\
\hline & & $200 \mu \mathrm{g} / \mathrm{ml}$ & 0.0 & $\mathrm{U}$ & 1.0 & $\mathrm{NC}$ \\
\hline & \multirow[t]{3}{*}{ CDDP } & $1 \mu \mathrm{g} / \mathrm{ml}$ & 0.0 & $\mathrm{U}$ & 1.0 & $\mathrm{NC}$ \\
\hline & & $5 \mu \mathrm{g} / \mathrm{ml}$ & 0.0 & $\mathrm{U}$ & 1.0 & $\mathrm{NC}$ \\
\hline & & $10 \mu \mathrm{g} / \mathrm{ml}$ & 0.0 & $\mathrm{U}$ & 0.8 & $\mathrm{NC}$ \\
\hline \multirow[t]{8}{*}{ SLMT-1 } & \multicolumn{2}{|c|}{$0.05 \%$ ethanol } & 1.0 & $\mathrm{NC}$ & 0.9 & $\mathrm{NC}$ \\
\hline & \multirow[t]{4}{*}{ GSE } & $50 \mu \mathrm{g} / \mathrm{ml}$ & 0.9 & $\mathrm{NC}$ & 1.1 & $\mathrm{NC}$ \\
\hline & & $75 \mu \mathrm{g} / \mathrm{ml}$ & 0.3 & $\mathrm{U}$ & 1.1 & $\mathrm{NC}$ \\
\hline & & $100 \mu \mathrm{g} / \mathrm{ml}$ & 0.3 & $\mathrm{U}$ & 0.8 & $\mathrm{NC}$ \\
\hline & & $200 \mu \mathrm{g} / \mathrm{ml}$ & 0.0 & $\mathrm{U}$ & 0.9 & $\mathrm{NC}$ \\
\hline & \multirow[t]{3}{*}{ CDDP } & $1 \mu \mathrm{g} / \mathrm{ml}$ & 0.8 & $\mathrm{U}$ & 0.9 & $\mathrm{NC}$ \\
\hline & & $5 \mu \mathrm{g} / \mathrm{ml}$ & 0.7 & $\mathrm{U}$ & 0.9 & $\mathrm{NC}$ \\
\hline & & $10 \mu \mathrm{g} / \mathrm{ml}$ & 0.3 & $\mathrm{U}$ & 1.1 & $\mathrm{NC}$ \\
\hline
\end{tabular}

$\mathrm{U}$, underexpression; $\mathrm{NC}$, no change in expression; O, overexpression. ${ }^{\mathrm{a}} \mathrm{Refer}$ to Table II legend for details.

change in the COX-1 expression level compared with NE1 (Table II).

For the GSE treatment of $48 \mathrm{~h}$, all the extracted RNA from the cell lines were of optimal quality for further expression analysis. An obvious reduction in the $\mathrm{COX}-2$ expression level was observed in all ESCC cell lines (8/8), and this inhibitory effect on COX-2 mRNA expression was GSE dosedependent (Table III). The effect of CDDP on the COX-2 mRNA level was also dose-dependent, except for KYSE 450, 520 and HKESC-3, in which no change in COX-2 expression was detected. In contrast, no change in COX-1 expression was observed in the 8 ESCC cell lines after both GSE and CDDP treatment for $48 \mathrm{~h}$ (Figs. 4 and 5).

As ethanol was used for GS extraction, its effects on both COX-1 and -2 expression were also investigated. The result showed that the expression of both genes were not altered by $0.05 \%$ ethanol, which was the maximum amount of solvent used in each MTS assay in all of the 8 ESCC cell lines (Figs. 4 and 5). The overall results of the expression study indicated that GSE downregulated the expression of COX-2 in a dosedependent manner without alteration of $\mathrm{COX}-1$ expression in all of the ESCC cell lines studied. A similar action of CDDP on the expression of COX-1 and -2 was also observed in the ESCC cell lines except for KYSE 450, 520 and HKESC-3.

\section{Discussion}

Surgery, radiotherapy, chemotherapy and multimodality therapy are the major approaches for treating different types of cancers. However, these treatments have various drawbacks. For example, surgery is an option only for observable and resectable tumors, and radiotherapy and chemotherapy result in a wide range of side effects. In contrast, natural products may be an alterative source of therapeutics against cancer. The anti-cancer properties of natural products with comparatively low toxicities, low costs and high abundance in the natural environment provide a source of valuable and novel alternatives to anti-cancer agents and can be used as neoadjuvants or even as a first-line cancer treatment (29). For instance, the extract of Brucea javanica was shown to induce apoptosis and has anti-proliferative functions on several human solid tumors such as non-small cell lung cancer, hepatocellular carcinoma, esophageal squamous cell carcinoma as well as breast cancer, and it has been widely used on the Chinese mainland as an alternative to cancer treatment (43). The extracts of other traditional Chinese medicines such as Gleditsia sinensis (26-32) and Rheum palmatum (44) have also been demonstrated for their anti-tumor effects on various types of cancers.

Compelling evidence shows that the overexpression of COX-2 is commonly found in a wide range of cancers (16) including esophageal squamous cell carcinoma (8). It has been well documented that COX-2 participates in carcinogenesis involving different roles (11-20). In addition, multiple lines of evidence demonstrate that the administration of COX-2 inhibitors and NSAIDs have both promising preventive and therapeutic benefits (18). In the present study, we demonstrated, for the first time, the selective inhibition on COX-2 expression in ESCC using GSE with an insignificant effect on the housekeeping COX-1 expression. The details concerning the mechanisms of inhibition are still subject to further investigations, even though the other molecular mechanisms of the anti-cancer effects of GSE have been extensively investigated previously by our team (26-32). 
KYSE 30

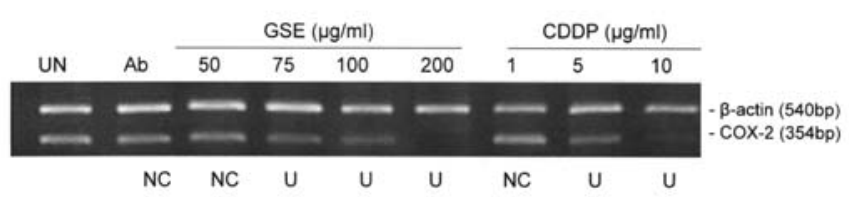

\section{KYSE 150}

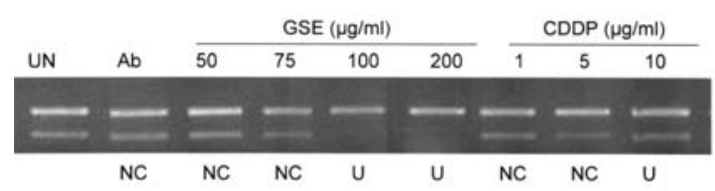

$\beta$-actin (540bp)

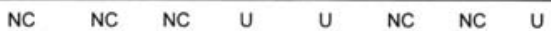

\section{KYSE 450}

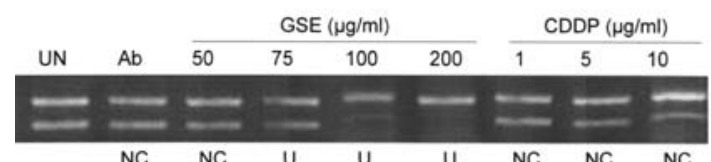

B-actin (540bp

KYSE 510

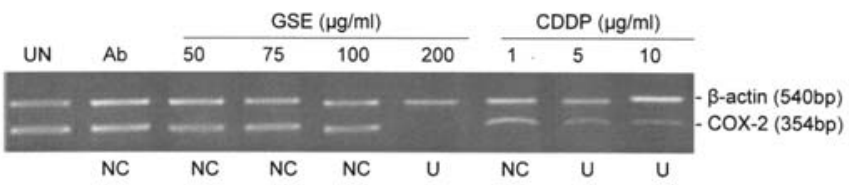

\section{KYSE 520}

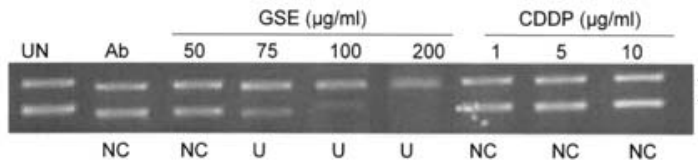
$\beta$-actin $(540 \mathrm{bp})$
$\operatorname{coX}-2(354 \mathrm{bp})$

\section{HKESC-3}

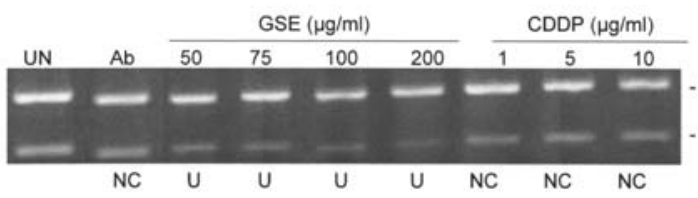

$\beta$-actin (540bp) COX-2 (354bp)

\section{HKESC-4}

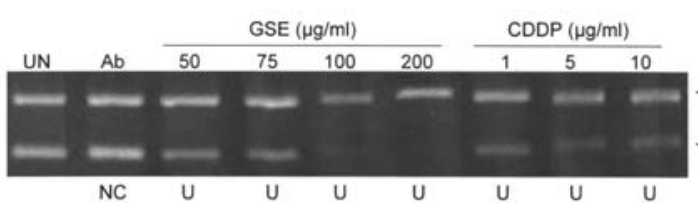

- - -actin (540bp) - coX-2 (354bp)

\section{SLMT-1}

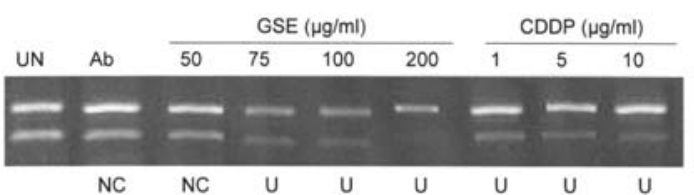

$\beta$-actin (540bp) - COX-2 (354bp)

Figure 4. Expression studies of COX-2 mRNA levels after GSE, CDDP and ethanol treatments. UN, untreated control; Ab, $0.05 \%$ ethanol-treated ESCC cells; U, underexpression; NC, no change in expression level. Results are summarized in Table III.
KYSE 30
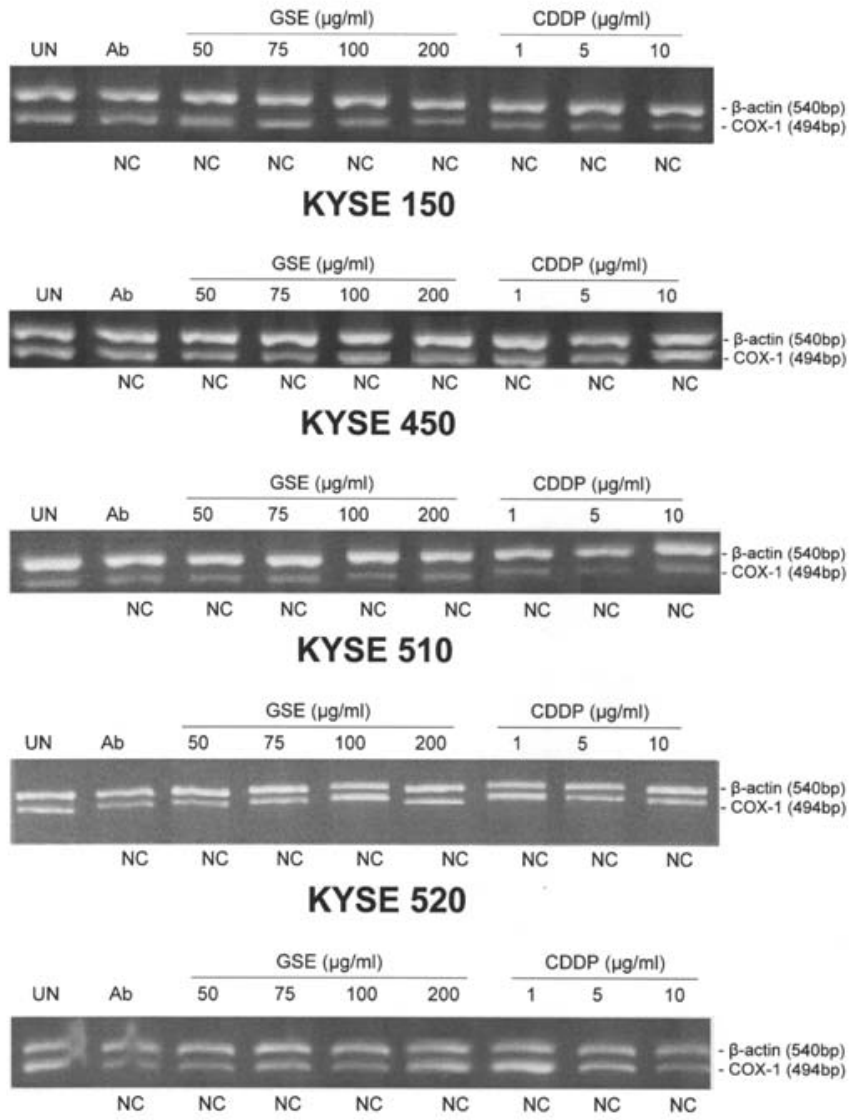

HKESC-3

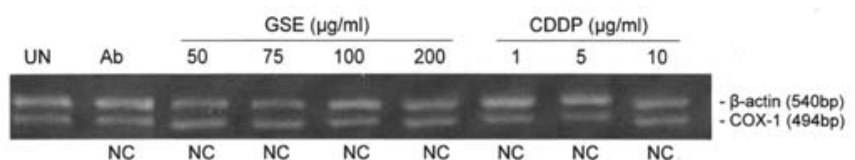

HKESC-4

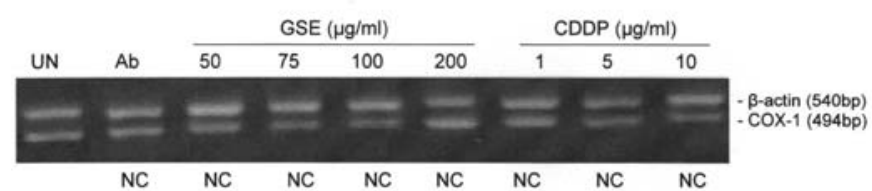

SLMT-1

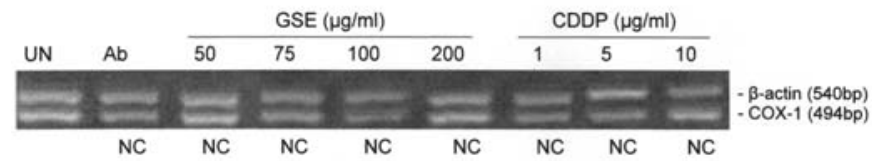

Figure 5. Expression studies of COX-1 mRNA levels after GSE, CDDP and ethanol treatments. UN, untreated control; Ab, $0.05 \%$ ethanol-treated ESCC cells; U, underexpression; NC, no change in expression level. Results are summarized in Table III.

For the MTS assays, in general, the doses of GSE for reaching the $\mathrm{MTS}_{50}$ values were higher than those of CDDP, however the toxicity of CDDP has been reported to be high in normal cells, and it has numerous well documented side effects such as induced neuropathies (45). Thus the study of 
GSE as a cytotoxic agent for targeting ESCC offers another opportunity to develop a possibly safer therapeutic agent in the long run.

Anchorage-independent clonogenicity assay is commonly used for evaluating the sensitivity of tumor cell lines to anticancer drugs (26). The inhibitory effect of GSE on colony formation of SLMT-1 in soft agar was demonstrated (32). The present result indicated that the colony-forming ability of ESCC cells was significantly reduced by half at a relatively lower dose of GSE (Fig. 2). Anchorage-independent growth reflects the ability by which cancer cells can still undergo cell division even without the attachment of extracellular matrix protein (46). Cancer cells bearing this aberrant growth property have higher potential to invade and/or metastasize to other internal body environments. In addition, the morphological monitoring of GSE-treated cells showed significant shrinkage of cells (data not shown) with an increased dose of GSE. Since GSE effectively diminished these selectable growth advantages of malignant cells, further studies can involve the use of GSE to suppress the metastatic potential of cancers.

Since COX-2 is involved in cancer development through a variety of mechanisms, overexpression of COX-2 is commonly found in many types of cancer. Hence, suppressing the expression of COX-2 is an attractive approach to target cancers which show upregulated COX-2 expression. In the present study, the semi-quantitative multiplex RT-PCR approach revealed that both GSE and CDDP repress COX-2 expression in a dose-dependent mode. Most importantly, a differential expression of COX-1 and COX-2 was observed after GSE or CDDP incubation, indicating the possible specific targeting effect of GSE on COX-2 expression. The expression of COX-1, which is a housekeeping gene essential for main-taining normal physiological process, was not significantly altered by the GSE and CDDP treatments. This result indicates that GSE and CDDP, unlike other NSAIDs and COX-2 inhibitors, may not cause deleterious side effects such as peptic ulceration and renal failure due to the suppression of COX-1 (20). Further animal tests are needed to confirm its specific suppression on COX-1 and side effects on the physiological systems.

To conclude, the results of the present study indicate that the anomalous fruit extract of Gleditsia sinensis possesses an anti-proliferative effect on ESCC cell lines, exerts a suppressive effect on the colony-forming ability of ESCC cells, and suppresses COX-2 expression but not COX-1 in a dose-dependent manner. Collectively, the present study reveals that one of the anti-cancer actions of GSE is through its modulatory effect on the COX-2 expression level. We believe that further development of GSE will play a critical role in advancing the anti-cancer therapy of esophageal squamous cell carcinoma as well as other types of cancers.

\section{Acknowledgements}

We acknowledge the donation of Mr. K.C. Lo for setting up the Lo Ka Chung Centre for Natural Anti-Cancer Drug Development and for supporting the research described in this report. The present study was also supported by the PolyU General Research Fund (grant no. G-U255), PolyU
Niche Area Fund (grant no. BB65) for the project 'Novel Anti-Cancer Small Molecule Drug R\&D' and the Niche Area Fund for the development of traditional Chinese medicine (grant no. BB8P). This research study is also part of the M.Phil. study of K.C. Pak.

\section{References}

1. Parkin DM, Bray F, Ferlya J and Pisani P: Global cancer statistics. CA Cancer J Clin 55: 74-108, 2005.

2. Lam AKY: Molecular biology of esophageal squamous cell carcinoma. Crit Rev Oncol Hematol 33: 71-90, 2000.

3. Law S and Wong J: Changing disease burdens and management issues for esophageal cancers in the Asia-Pacific region. J Gastroenterol Hepatol 17: 374-381, 2002.

4. Chandrasekharan NV and Simmons DL: The cyclooxygenases. Genome Biol 5: 241, 2004.

5. Dubois RN, Abramson SB, Crofford L, Gupta RA, Simon LS, Putte LBAVD and Lipsky PE: Cyclooxygenase in biology and disease. FASEB J 12: 1063-1073, 1998.

6. Tanabe T and Tohnai N: Cyclooxygenase isozymes and their gene structures and expression. Prostaglandins Other Lipid Mediat 68-69: 95-114, 2002.

7. Hinz B and Brune K: Cyclooxygenase-2 10 years later. J Pharmacol Exp Ther 300: 367-375, 2001

8. Zimmermann KC, Sarbia MA, Weber AA, Borchard F, Gabbert HE and Schror K: Cyclooxygenase-2 expression in human esophageal carcinoma. Cancer Res 59: 198-204, 1999.

9. Liu CH, Chang Sh, Narko K, Trifan OC, Wu MT, Smith E, Haudenschild C, Lane TF and Hla T: Overexpression of cyclooxygenase-2 is sufficient to induce tumorigenesis in transgenic mice. J Biol Chem 276: 18563-18569, 2001.

10. Zhi H, Wang L, Zhang J, Zhou C, Ding F, Luo A, Wu M, Zhan Q and Liu Z: Significance of COX-2 expression in human esophageal squamous cell carcinoma. Carcinogenesis 27: 1214-1221, 2006.

11. Kase S, Osaki M, Honjo S, Adachi H, Tsujitani S, Kaibara N and Ito H: Expression of cyclooxygenase-2 is correlated with high intratumoral microvessel density and low apoptotic index in human esophageal squmaous cell carcinomas. Virchows Arch 442: 129-135, 2003.

12. Leahy KM, Koki AT and Masferrer JL: Role of cyclooxygenases in angiogenesis. Curr Med Chem 7: 1163-1170, 2000.

13. Mazhar D, Gillmore R and Waxman J: COX and cancer. Q J Med 98: 711-718, 2005.

14. Wang W, Bergh A and Damber JE: Cyclooxygenase-2 expression correlates with local chronic inflammation and tumor neovascularization in human prostate cancer. Clin Cancer Res 11: 3250-3256, 2005.

15. Williams CS, Mann M and DuBois RN: The role of cyclooxygenase-2 in inflammation, cancer, and development. Oncogene 18: 7908-7916, 1999.

16. Subbaramaiah K and Dannenberg AJ: Cyclooxygenase 2: a molecular target for cancer prevention and treatment. Trends Pharmacol Sci 24: 96-102, 2003.

17. Xu XC: COX-2 inhibitors in cancer treatment and prevention, a recent development. Anticancer Drugs 13: 127-137, 2002.

18. Altork N: COX-2: A target for prevention and treatment of esophageal cancer. J Surg Res 117: 114-120, 2004.

19. Schreinemachers DM and Everson RB: Aspirin use and lung, colon, and breast cancer incidence in a prospective study. Epidemiology 5: 138, 1994.

20. Hawkey CJ and Langman MJS: Non-steroidal anti-inflammatory drugs: overall risks and management. Complementary role for COX-2 inhibitors and proton pump inhibitors. Gut 52: 600-608, 2003.

21. Andersohn F, Suissa S and Garbe E: Use of first- and secondgeneration cyclooxygenase-2-selective nonsteroidal antiinflammatory drugs and risk of acute myocardial infarction. Circulation 113: 1950-1957, 2006.

22. Chow LCM, Tang JCO, Teo ITN, Chui CH, Lau FY, Leung TWT, Cheng G, Wong RSM, Wong ILK, Tsang KMS, Tan WQ, Zhao YZ, Lai KB, Lam WH, Guo DA and Chan ASC: Antiproliferative activity of the extract of Gleditsia sinensis fruit on human solid tumour cell lines. Chemotherapy 48: 303-308, 2002.

23. Zhang Z, Koike K, Jia Z, Nikaido T, Guo D and Zheng J: Triterpenoidal saponins from Gleditsia sinensis. Phytochemistry 52: 715-722, 1999. 
24. Kim JC, Park JH, Budesinsky M, Kasal A, Han YH, Koo BS, Lee SI and Lee DU: Antimutagenic constituents from the thorns of Gleditsia sinensis. Chem Pharm Bull 53: 561-564, 2005.

25. Zhong L, Li P, Ha J, Qu G and Guo D: Structure-activity relationships of saponins from Gleditsia sinensis in cytotoxicity and induction of apoptosis. Planta Med 70: 797-802, 2004.

26. Chow LMC, Chui CH, Tang JCO, Teo ITN, Lau FY, Cheng GYM, Wong RSM, Leung TWT, Lai KB, Yau MYC, Guo D and Chan ASC: Gleditsia sinensis fruit extract is a potential chemotherapeutic agent in chronic and acute myelogenous leukemia. Oncol Rep 10: 1601-1607, 2003.

27. Chui CH, Tang JCO, Lau FY, Teo ITN, Yau MYC, Wong RSM, Cheng GYM, Ho SKW, Leung TWT, Hui KS and Wong MM: Gleditsia sinensis fruit extract-induced growth inhibition involves basic fibroblast growth factor and nitric oxide. Int J Mol Med 13: 169-173, 2004.

28. Chow LMC, Chui CH, Tang JCO, Lau FY, Yau MYC, Cheng GYM, Wong RSM, Lai PBS, Leung TWT, Teo ITN, Cheung F, Guo D and Chan ASC: Anti-angiogenic potential of Gleditsia sinensis fruit extract. Int J Mol Med 12: 269-273, 2003.

29. Chui CH, Lau DFY, Chan ASC, Cheng GYM, Wong RSM, Lai KB, Kok SHL, Au Yeung TTL, Teo ITN, Yau MYC, Cheung F, Cheng $\mathrm{CH}$ and Tang JCO: Gleditsia sinensis fruit extract-induced apoptosis involves changes of reactive oxygen species level, mitochondrial membrane depolarization and caspase 3 activation. Int J Mol Med 15: 539-543, 2005.

30. Cheung F, Chui CH, Chan ASC, Lau FY, Cheng GYM, Wong RSM, Kok SHL, Teo ITN, Cheng CH and Tang JCO: Inhibition of proteasome activity in Gleditsia sinensis fruit extract-mediated apoptosis on human carcinoma cells. Int J Mol Med 16: 925-929, 2005.

31. Teo ITN, Tang JCO, Chui CH, Cheng GYM, Yau MYC, Lau FY, Wong RSM, Leung TWT, Cheung F, Ho KP, Cheng $\mathrm{CH}$ and Chan ASC: Superoxide anion is involved in the early apoptosis mediated by Gleditsia sinensis fruit extract. Int J Mol Med 13: 909-913, 2004

32. Tang WK, Chui CH, Fatima S, Kok SHK, Pak KC, Ou TM, Hui KS, Wong MM, Wong J, Law S, Tsao SW, Lam KY, Beh PSL, Srivastava G, Ho KP, Chan ASC and Tang JCO: Inhibitory effects of Gleditsia sinensis fruit extract on telomerase activity and oncogenic expression in human esophageal squamous cell carcinoma. Int J Mol Med 19: 953-960, 2007.

33. Hu YC, Lam KY, Law SY, Wan TSK, Ma ESK, Kwong YL, Chan LC, Wong J and Srivastava G: Establishment, characterization, karyotyping, and comparative genome hybridization analysis of HKESC-2 and HKESC-3: two newly established human esophageal squamous cell carcinoma cell lines. Cancer Genet Cytogenet 135: 120-127, 2002.

34. Cheung LCM, Tang JCO, Lee PY, Hu L, Guan XY, Tang WK, Srivastava G, Wong J, Luk JM and Law S: Establishment and characterization of a new xenograft-derived human esophageal squamous cell carcinoma cell line HKESC-4 of Chinese origin. Cancer Genet Cytogenet 178: 17-25, 2007.
35. Tang JCO, Wan TSK, Wong N, Pang E, Lam KY, Law SY, Chow LMC, Ma ESK, Chan LC, Wong J and Srivastava G: Establishment and characterization of a new xenograft-derived human esophageal squamous cell carcinoma cell line SLMT-1 of Chinese origin. Cancer Genet Cytogenet 124: 36-41, 2001.

36. Shimada $\mathrm{Y}$, Imamura $\mathrm{M}$, Wagata $\mathrm{T}$, Yamaguchi $\mathrm{N}$ and Tobe $\mathrm{T}$ : Characterization of 21 newly established esophageal cancer cell lines. Cancer 69: 277-284, 1992.

37. Fatima S, Chui CH, Tang WK, Hui KS, Au HW, Li WY, Wong MM, Cheung F, Tsao SW, Lam KY, Beh PSL, Wong J, Law S, Srivastava G, Ho KP, Chan ASC and Tang JCO: Transforming capacity of two novel genes $J S-1$ and $J S-2$ located in chromosome $5 \mathrm{p}$ and their overexpression in human esophageal squamous cell carcinoma. Int J Mol Med 17: 159$170,2006$.

38. Zhang H, Jin YS, Chen XH, Jin C, Law S, Tsao SW and Kwong YL: Cytogenetic aberrations in immortalization of esophageal epithelial cells. Cancer Genet Cytogenet 165: 25-35, 2006.

39. Hussain T, Gupta S, Adhami VM and Mukhtar H: Green tea constituent epigallocatechin-3-gallate selectively inhibits COX-2 without affecting COX-1 expression in human prostate carcinoma cells. Int J Cancer 113: 660-669, 2005.

40. Kang K, Kubin M, Cooper KD, Lessin KD, Trinchieri G and Rook AH: IL-12 synthesis by human langerhan cells. J Immunol 156: 1402-1407, 1996.

41. Miyazono F, Metzger R, Warnecke-Eberz U, Baldus SE, Brabender J, Bollschweiler E, Doerfler W, Mueller RP, Dienes HP, Aikou T, Hoelscher AH and Schneider PM: Quantitative c-erbB-2 but not c-erbB-1 mRNA expression is a promising marker to predict minor histopathologic response to neoadjuvant radiochemotherapy in oesphageal cancer. Br J Cancer 91: 666-672, 2004

42. Zhou C, Liu S, Zhou X, Xue L, Quan L, Lu N, Zhang G, Bai J, Wang Y, Liu Z, Zhan Q, Zhu $\mathrm{H}$ and Xu N: Over-expression of human pituitary tumor transforming gene $(h P T T G)$ is regulated by $\beta$-catenin/TCF pathway in human esophageal squamous cell carcinoma. Int J Cancer 113: 891-898, 2005.

43. Lau FY, Chui CH, Gambari R, Kok SHL, Kan KL, Cheng GYM, Wong RSM, Teo ITN, Cheng CH, Wan TSK, Chan ASC and Tang JCO: Antiproliferative and apoptosis-inducing activity of Brucea javanica extract on human carcinoma cells. Int $\mathrm{J}$ Mol Med 16: 1157-1162, 2005.

44. Shoemaker M, Hamilton B, Dairkee SH, Cohen I and Campbell MJ: In vitro anticancer activity of twelve Chinese medicinal herbs. Phytother Res 19: 649-651, 2005.

45. Klein R, Brown D and Turnle AM: Phenoxodiol protects against Cisplatin-induced neurite toxicity in a PC-12 cell model. BMC Neurosci 8: 61, 2007.

46. Schwartz MA: Integrins, oncogenes, and anchorage independence. J Cell Biol 139: 575-578, 1997. 